\title{
Risk of violence-related injury from alcohol consumption and its burden to society in Latin America and the Caribbean
}

\author{
Cheryl J. Cherpitel, ${ }^{1}$ Yu Ye, ${ }^{1}$ and Maristela Monteiro ${ }^{2}$
}

Suggested citation

Cherpitel CJ, Ye Y, Monteiro M. Risk of violence-related injury from alcohol consumption and its burden to society in Latin America and the Caribbean. Rev Panam Salud Publica. 2018;42:e7. https://doi. org/10.26633/RPSP.2018.7

\begin{abstract}
Objective. To determine the relative risk $(R R)$ and societal burden of injury related to alcohol-attributable intentional interpersonal violence (alcohol-attributable fraction or AAF), and the dose-response relationship, in Latin America and the Caribbean (LAC), where both the RR and AAF for violence-related injuries are believed to be particularly high.

Methods. A probability sample of 1024 emergency department patients from 10 LAC countries who reported an intentional interpersonal violence-related injury (IVRI) was analyzed using case-crossover fractional polynomial analysis of the number of drinks consumed prior to the event.

Results. A dose-response relationship with a sixfold increase in risk $(R R=5.6)$ for up to two drinks prior to injury was observed. Risk was higher for 1) females versus males at more than 10 drinks and 2) males and females 30+ years old versus those younger than 30 at all volume levels. Overall, 32.7\% of the 1024 intentional IVRIs were attributable to alcohol. The AAF was three times larger for males (38\%) than for females (12.3\%).

Conclusions. A dose-response relationship between the volume of alcohol consumed prior to the event and the risk of intentional IVRI was found. Risk was not uniform across gender or age. Females were at greater risk of injury compared to males at higher volumes of drinking but had a lower AAF due to their lower prevalence of drinking at higher levels.
\end{abstract}

Keywords Violence; wounds and injuries; risk; alcohol drinking; Latin America; Caribbean region.
In the estimates for the Global Burden of Diseases, Injuries, and Risk Factors Study 2010 (GBD 2010), alcohol is the fifth leading risk factor for Latin America and the Caribbean (LAC) (1). Injuries constitute one-third of alcohol-attributable disability-adjusted life years (DALYs) in the LAC region

\footnotetext{
Alcohol Research Group, Emeryville, California, United States of America. Send correspondence to: Cheryl J. Cherpitel, ccherpitel@arg.org

2 Pan American Health Organization, Washington, D.C., United States of America.
}

(versus $42 \%$ in the Americas), and $12 \%$ of them are from intentional interpersonal violence (versus $19.5 \%$ in the Americas) $(1,2)$.

Relative risk (RR) of injury from alcohol consumption is an important factor to consider when estimating the alcohol-attributable fraction (AAF) of injury. Risk is usually derived from 1) mortality data (rather than morbidity data) and 2) measures of chronic consumption of alcohol (rather than acute consumption) (3), with the latter measure more relevant when the research interest is the immediate effect of drinking on an event, such as injury (4). In addition, most risk estimates do not examine the dose-response relationship. Finally, risk estimates typically assume uniform risk across different alcohol consumption levels, gender and age groups, causes of injury, and countries or regions, so most research on the AAF of injury derived from RR estimates does not consider the effects of these potentially important moderating variables. 
A stronger association has been found between alcohol consumption and injuries resulting from intentional interpersonal violence than for injuries from any other causes $(5,6)$. Much of the literature documenting this association has come from studies conducted in hospital emergency departments (EDs) $(7,8)$, using either case-control studies, in which noninjured patients serve as quasi-controls (9), or case-crossover studies, in which injured patients serve as their own controls $(10,11)$.

In addition, a stronger dose-response relationship has been found for injuries resulting from intentional interpersonal violence than for injuries from any other causes (11-14). A meta-analysis found 1) the risk of injury from acute alcohol consumption was greater for intentional interpersonal violence-related injury (IVRI) than for injury from any other causes, and 2) there was a 1.38 increase in risk for that type of injury for each drink consumed prior to the event (14). Analysis of ED data across 18 countries found the RR of intentional IVRI increased monotonically with an increase in the amount of alcohol consumed in the six hours prior to the event (from 3.5 for 1 drink to 32.9 for 30 or more drinks) (13).

The AAF has also been found to be greater for intentional IVRI than for injuries from any other causes $(9,15,16)$. A six-country case-control study found $43 \%$ of intentional IVRIs occurred after drinking in the six hours prior to the event and $27 \%$ occurred among frequent heavy drinkers, compared to $6 \%$ of injuries from other causes for both risk factors (9). A Swiss ED study found an AAF of $33 \%$ for intentional IVRI and an AAF of $17 \%$ for injuries from other causes (15), and a study across EDs from 18 countries found an AAF of $40.1 \%$ for intentional IVRI compared to an AAF of $12 \%$ for injuries from other causes (16).

Country-level drinking patterns have been found to predict alcohol-related injury in ED studies $(17,18)$, and both the RR of injury and the AAF have been found to vary by drinking pattern; countries with higher detrimental drinking patterns (DDPs) (19) (exemplified by heavy episodic drinking) have been found to have a larger risk of injury at lower levels of consumption (13), and a higher $\operatorname{AAF}(9,16)$. Countries with similar DDPs often cluster in a given region, and those in Central America tend to exhibit more DDPs than those in other areas of the Americas.

Drinking patterns have been found to contribute to the large burden of alcohol-attributable disease in LAC countries, where they result in the largest burden of alcohol-attributable injuries worldwide $(2,20,21)$. A comparison of intentional IVRIs in female ED patients in developing countries and those in developed countries found women in developing countries were more likely to report frequent and heavy drinking patterns and more likely to have injuries related to intentional interpersonal violence than those in developed countries (22).

The purpose of this report was to determine the RR and societal burden of injury related to intentional interpersonal violence attributable to drinking (the AAF), and the dose-response relationship, in LAC countries, where both the RR and AAF are believed to be particularly high. The dose-response relationship of alcohol and intentional IVRI was modeled separately by gender, and age group, using the fractional polynomial approach. Risk of injury from drinking within the six-hour timeframe preceding the event was estimated using case-crossover analysis. These data are essential for determining the burden of disease from intentional IVRI in the LAC region, much of which is avoidable $(18,23)$.

\section{MATERIALS AND METHODS}

\section{Samples}

The analyzed data were from 18 ED sites in 10 LAC countries and were collected according to the protocols developed for the Emergency Room Collaborative Alcohol Analysis Project (ERCAAP) and the World Health Organization (WHO) Collaborative Study on Alcohol and Injuries (17). The majority of EDs were in public hospitals in large metropolitan areas, generally the capital city of the country. Identical protocols were used across the 10 studies, which included probability samples of patients $18+$ years old who had arrived at the ED within six hours of an injury event. Sampling was based on ED admission forms for injury patients (ambulatory, and nonambulatory, brought by ambulance). At each site, a sampling strategy was implemented in which every "nth" injury patient $\left(2^{\text {nd }}, 3^{\text {rd }}, 4^{\text {th }}\right.$, etc., depending on how many were admitted to the ED), based on order of admission, was selected. If a patient refused to participate or could not be interviewed for some other reason the next "nth" patient was selected. This sampling strategy was designed this way to provide equal representation of each shift and day of the week.

Sampled patients were approached by the research team members who requested their informed consent to participate in the study, and those consenting were administered a 25-minute structured questionnaire (24) by trained interviewers, usually off-duty ED staff or students from psychology or health sciences departments or other related areas. Completion rates averaged $72 \%$ across all studies ( $n=5$ 176). Reasons for noninterviews included patient 1) refusal of informed consent, 2) incapacitation/hospitalization, 3) departure from hospital before completing the survey questions, 4) in police custody, and 5) language barriers. Some patients who could not provide consent during their admission to the ED due to incapacitation/hospitalization were approached after their condition had stabilized and, if consent was provided, interviewed. Of those completing the interview, 20\% $(n=1037)$ had an intentional IVRI (Table 1).

\section{Measures}

Among other questions, patients were asked about the injury for which they were seeking ED treatment. Patients responding positively to the question "Did you get into a fight, or were you beaten, attacked, or raped?" were considered to have an intentional IVRI. As the purpose of the study was to explore the relationship between alcohol consumption and intentional interpersonal violence, injuries related to other types of violence, such as motor vehicle crashes, were not included. All patients with an injury related to intentional interpersonal violence were included in the sampling regardless of whether they were the victim or the perpetrator of the event.

Patients were also asked if they had consumed any alcohol during 1) the six hours leading up to the injury event or 2) the same six-hour period the week before. If patients reported drinking during either time period they were asked to report the number and size of container of drinks consumed, by beverage type, for each one. The amount of absolute alcohol for each beverage was then calculated, 
summed across all beverage types for each time period, and converted to standard drinks, defined as $16 \mathrm{ml}$ (12.8 g) of pure ethanol.

\section{Data analysis}

Case-crossover analysis (25) was used to compare each injury patient's drinking in the six-hour period before injury to their drinking within the same sixhour period the week before. Using this method, each patient served as his or her own control, reducing the effect of individual-level factors that could affect the relationship between alcohol and the injury.

Using the fractional polynomial approach, the dose-response relationship for alcohol (with the volume of consumption as a continuous measure) and risk of intentional IVRI were modeled (26), based on the conditional logistic equation below (where $p$ and $q$ are designated as $-2,-1,-0.5,0,0.5,1$, 2 , or $3\left(x^{0}=\ln (x)\right)$ and $x$ is some transformed form of volume consumption) (13):

$\operatorname{logit}(\operatorname{Prob}$ (injury) $)=\mathrm{b}_{0}+\mathrm{b}_{1} \mathrm{x}^{p}+\mathrm{b}_{2} \mathrm{x}^{q}\left(\right.$ or $\mathrm{b}_{0}+$ $\mathrm{b}_{1} \mathrm{x}^{p}+\mathrm{b}_{2} \mathrm{x}^{p}(\ln \mathrm{x})$ if $\left.p=q\right)$

The fracpoly command from Stata Statistical Software version 13 (27) was used to fit all models.

Next, the population AAF (the proportion of intentional IVRI cases attributable to alcohol for all levels of consumption) and the specific-volume AAFs or SVAAFs (the AAFs for each specific volume of alcohol consumption shown in the first column of Table 2) were calculated. The SVAAFs were obtained using RR estimates for the mean volume and prevalence of drinking during the six hours before injury in each volume category, as shown in the equation below (where $i$ refers to a volume category):

$$
\begin{aligned}
A A F_{i} & =P_{i}(\text { Alcohol } \mid \text { injury }) \\
& \times\left(1-\frac{1}{R R_{i}}\right)(28)
\end{aligned}
$$

The population AAF was calculated by summing the SVAAFs, using the equation below:

$$
\begin{aligned}
A A F_{p o p} & =\sum P_{i}(\text { Alcohol } \mid \text { injury }) \\
& \times\left(1-\frac{1}{R R_{i}}\right)(28)
\end{aligned}
$$

The RR, SVAAFs, and population AAFs were estimated for the total sample and by gender and age group (18-30 years versus $30+$ years). The estimates of risk and SVAAF for 30 or fewer drinks (and up to 10 drinks, for females, in a subgroup analysis, due to sparse data for that group at higher consumption levels) are shown in Tables 2-4. Age was dichotomized at 30 years because people 18-30 years old have been found to report higher rates of alcohol consumption and alcohol-related problems than those $30+$ years old (29).

\section{RESULTS}

Table 1 lists the 10 countries in the study sample, the year of data collection, the number of ED sites in each country, and the cities where the data were collected. Table 1 also shows the proportion of injuries that were intentional interpersonal violence-related $(20 \%)$, and alcohol-related $(38 \%)$, based on injury patients' self-reported alcohol consumption during the six hours before the injury event. In some countries, data were collected at more than one site due to the demographic diversity and/or size of the population served in the respective locales. The proportion of intentional IVRI and alcohol-related injury varied greatly across countries, with the values for the first criterion ranging from $9 \%$ in Brazil and Costa Rica to $44.7 \%$ in Guyana and those for the second criterion ranging from $25.5 \%$ (in Trinidad and Tobago) to $52.3 \%$ (in Argentina). As shown in Table 1, a larger proportion of injury patients reported drinking during the six hours before the injury event in countries with a lower versus a higher prevalence of intentional IVRIs.

Estimates of 1) the RR of intentional IVRI for each volume level of drinking before injury, 2) the proportion of injuries attributable to alcohol at each SVAAF, and 3) the total population AAF (for the sample overall) are shown in Table 2 . The results indicated a dose-response relationship between the amount of alcohol consumed

\begin{tabular}{|c|c|c|c|c|c|c|}
\hline \multirow{3}{*}{ Country (cities) } & \multirow{3}{*}{ Year of study } & \multirow{3}{*}{$\begin{array}{l}\text { Number of } \\
\text { EDs studied }\end{array}$} & \multirow{3}{*}{ Total } & \multicolumn{3}{|c|}{ ED injury cases } \\
\hline & & & & \multicolumn{3}{|c|}{ Intentional interpersonal violence-related } \\
\hline & & & & No. & $\%$ of total injury cases & $\begin{array}{l}\text { Prevalence of drinking } \\
\text { before injury (\%) }\end{array}$ \\
\hline Argentina (Mar del Plata) & 2001 & 1 & 452 & 55 & 10.1 & 52.3 \\
\hline Brazil (São Paulo) & 2001 & 1 & 496 & 45 & 9.1 & 35.6 \\
\hline Mexico (Mexico City) & 2002 & 1 & 456 & 72 & 15.8 & 50.0 \\
\hline Dominican Republic (Santo Domingo) & 2010 & 2 & 501 & 95 & 19.0 & 30.1 \\
\hline Guatemala (Guatemala City) & 2011 & 1 & 513 & 130 & 25.3 & 43.1 \\
\hline Guyana (Georgetown) & 2010 & 1 & 485 & 217 & 44.7 & 30.0 \\
\hline Nicaragua (Managua) & 2010 & 2 & 518 & 187 & 36.1 & 37.8 \\
\hline Panama (La Chorrera, Colón, and Veraguas) & 2010 & 3 & 490 & 90 & 18.4 & 46.1 \\
\hline Costa Rica (San José) & 2012 & 2 & 1013 & 90 & 8.9 & 40.9 \\
\hline $\begin{array}{l}\text { Trinidad and Tobago (Mt. Hope, San Fernando, Port- } \\
\text { of-Spain, and Scarborough) }\end{array}$ & 2015 & 4 & 252 & 56 & 22.2 & 25.5 \\
\hline Total & - & 18 & 5176 & 1037 & 19.9 & 37.9 \\
\hline
\end{tabular}
before the injury event and risk of

TABLE 1. Number and proportion (\%) of emergency department (ED) injury cases ( $n=5$ 176) related to intentional interpersonal violence, and prevalence of drinking before injury (\%), at 18 EDs in 10 countries, Latin American and the Caribbean, $2001-2015$

Source: Compiled by the authors based on the study data.

a Prevalence rates are not an exact match to sample numbers because the Argentina data were weighted to adjust for uneven sampling. 
TABLE 2. Estimated relative risk (RR) and alcohol-attributable fraction (AAF) of intentional interpersonal violence-related injuries (IVRIs) $(n=1 \mathrm{024})$, with $95 \%$ confidence intervals $(\mathrm{Cls})$, by volume of alcohol consumed pre-injury, Latin America and the Caribbean, ${ }^{\text {2 } 2001-2015}$

\begin{tabular}{|c|c|c|c|c|c|}
\hline $\begin{array}{l}\text { Alcohol intake before injury } \\
\text { (number of drinks) }\end{array}$ & No. of intentional IVRIs & $\begin{array}{l}\text { Prevalence of drinking } \\
\text { before injury }(\%)^{b}\end{array}$ & Relative risk $(\mathrm{RR})^{\mathrm{c}}$ & $\operatorname{AAF}(\%)^{d}$ & $95 \% \mathrm{Cls}$ \\
\hline 0 & 634 & - & - & - & - \\
\hline$\leq 2$ & 54 & 5.18 & 5.59 & 4.25 & $2.89,5.59$ \\
\hline $4.1-6$ & 50 & 4.82 & 7.83 & 4.20 & $2.89,5.50$ \\
\hline $6.1-8$ & 43 & 4.30 & 8.02 & 3.76 & $2.50,5.01$ \\
\hline $8.1-10$ & 28 & 2.71 & 8.15 & 2.37 & $1.38,3.36$ \\
\hline $15.1-30$ & 42 & 4.14 & 8.29 & 3.64 & $2.41,4.86$ \\
\hline$>30$ & 46 & 4.45 & 8.70 & 3.94 & $2.67,5.18$ \\
\hline Missing ${ }^{\mathrm{e}}$ & 18 & 1.72 & 4.90 & 1.37 & $0.59,2.14$ \\
\hline Total $^{\mathrm{T}}$ & 1024 & 37.88 & & 32.72 & \\
\hline
\end{tabular}

Source: Compiled by the authors based on the study data.

${ }^{a}$ Argentina, Brazil, Costa Rica, Dominican Republic, Guatemala, Guyana, Mexico, Nicaragua, Panama, Trinidad and Tobago.

${ }^{\mathrm{b}}$ Prevalence rates are not an exact match to sample numbers because the Argentina data were weighted to adjust for uneven sampling.

${ }^{\circ}$ Fractional polynomial estimates based on the mean volume of each volume category (e.g., 1.35 drinks, for the $\leq 2$ drinks volume category).

${ }^{d}$ Specific-volume AAF (SVAAF): $P_{i}^{*}(1-1 /$ RR $)$, in which $P_{i}$ is the prevalence of drinking at a given volume level among total injured patients (cases) and RR the relative risk of injury for a given volume level compared to no drinking.

${ }^{e}$ Those who reported drinking before injury but didn't report specific volume of consumption. As a conservative estimate, the RR for 1 drink is used for this missing group.

${ }^{\mathrm{f}}$ The total includes the sum of the prevalence and SVAAF across dose levels among all patients for which drinking data were available.

intentional IVRI, with a sixfold increase in risk for up to two drinks, and a nearly ninefold increase for more than 30 drinks. While risk of injury increased at each volume level, the SVAAF estimates-which ranged from 2.4 for $8.1-10$ drinks prior to injury to 5.4 for 2.1-4 drinks prior to injury-did not. Among the ED sample, the prevalence of drinking before an intentional IVRI was $37.9 \%$, and the AAF was $32.7 \%$. Therefore, the "exposed" AAF (the proportion of injuries attributed to alcohol among those who reported drinking during the six hours before their injury) was $32.7 / 37.9$ or $86 \%$.

The RR, SVAAF, and population AAF estimates are shown separately by gender in Table 3. The risk of injury for "up to 10 drinks" was similar for males and females, but beyond 10 drinks, the RR was higher for females. However, due to a smaller prevalence of females compared to males drinking at higher volume levels (more than 10 drinks), females' estimated population AAF (12.3\%) was only one-third of males' (38\%). Males showed a slightly higher "exposed" AAF compared to females $(38.0 / 43.9$ or $86.5 \%$ versus $12.3 / 14.8$ or $83.1 \%$ ).

Table 4 shows the RR, SVAAF, and population AAF estimates for injury patients 30+ years old and 18-30 years old. Risk was higher for the first group at all volume levels over two drinks, with a threefold greater risk at more than 30 drinks. At each volume level, risk of injury appeared to continue to increase for people $30+$ years old, while RR estimates dropped after 30 drinks for those who were younger. The population AAF was slightly higher for those $30+$ years old (34.3\%) compared to those who were younger (32\%), and the "exposed" AAF was also slightly higher (88.6\% versus $85.1 \%$ ).

\section{DISCUSSION}

In the LAC region, a dose-response relationship was found between alcohol consumed during the six hours before the injury event and alcohol-related injury, with a population AAF of $32.7 \%$ and an "exposed" AAF of $86 \%$. A study in a Swiss ED using a case-control design found an AAF of $36 \%$ for drinking during the 24 hours preceding the event, close to the proportion found in this study (15). A similar, prior analysis of 18 countries (including all countries studied in the research reported here except Costa Rica and Trinidad and Tobago) found a population AAF of $40.1 \%$ and an "exposed" AAF of $90.7 \%$ for intentional IVRIs (16); both measures were somewhat higher than those found in this study, and the first one was considerably higher than the AAF for injuries from motor vehicle crashes $(11.1 \%)$, falls $(14.3 \%)$, and other causes of injury $(9.8 \%)$. The population AAF found in this study is also lower than the one found in an earlier case-control study of ED patients across six countries (43\%) (9).
In this study, risk of intentional IVRI was similar for males and females at lower volume levels but greater for females at higher levels (more than 10 drinks). The population AAF for females was only one-third of males' $(12.3 \%$ versus $38 \%$ ), due to females' lower prevalence of drinking at higher levels, but the "exposed" AAF was only slightly higher, suggesting that intentional IVRI was similarly attributable to alcohol for both males and females who reported drinking prior to the injury event. Other ED studies have found gender differences in drinking and intentional IVRIs, with a significantly greater association for males compared to females in some, but not all, countries (30).

Risk of intentional IVRI was found to be greater at all volume levels exceeding two drinks for those older than 30 years, compared to those who were younger, and continued to increase at each successive volume level for the older age group, while dropping after 30 drinks before injury for those who were younger. However, for those more than 30 years old, the population AAF was only slightly larger, as was the "exposed" $\mathrm{AAF}$, suggesting that among those reporting drinking prior to their injury, regardless of age, intentional IVRI was similarly attributable to alcohol. While other studies have found that younger individuals have certain characteristics (e.g., risk-taking, impulsivity and sensation-seeking dispositions, and other 
TABLE 3. Estimated relative risk (RR) and alcohol-attributable fraction (AAF) of intentional interpersonal violence-related injuries (IVRIs) $(n=1024)$, with $95 \%$ confidence intervals (Cls), by volume of alcohol consumed pre-injury for males $(n=814)$ and females $(n=210)$, Latin America and the Caribbean, ${ }^{\mathrm{a}} 2001-2015$

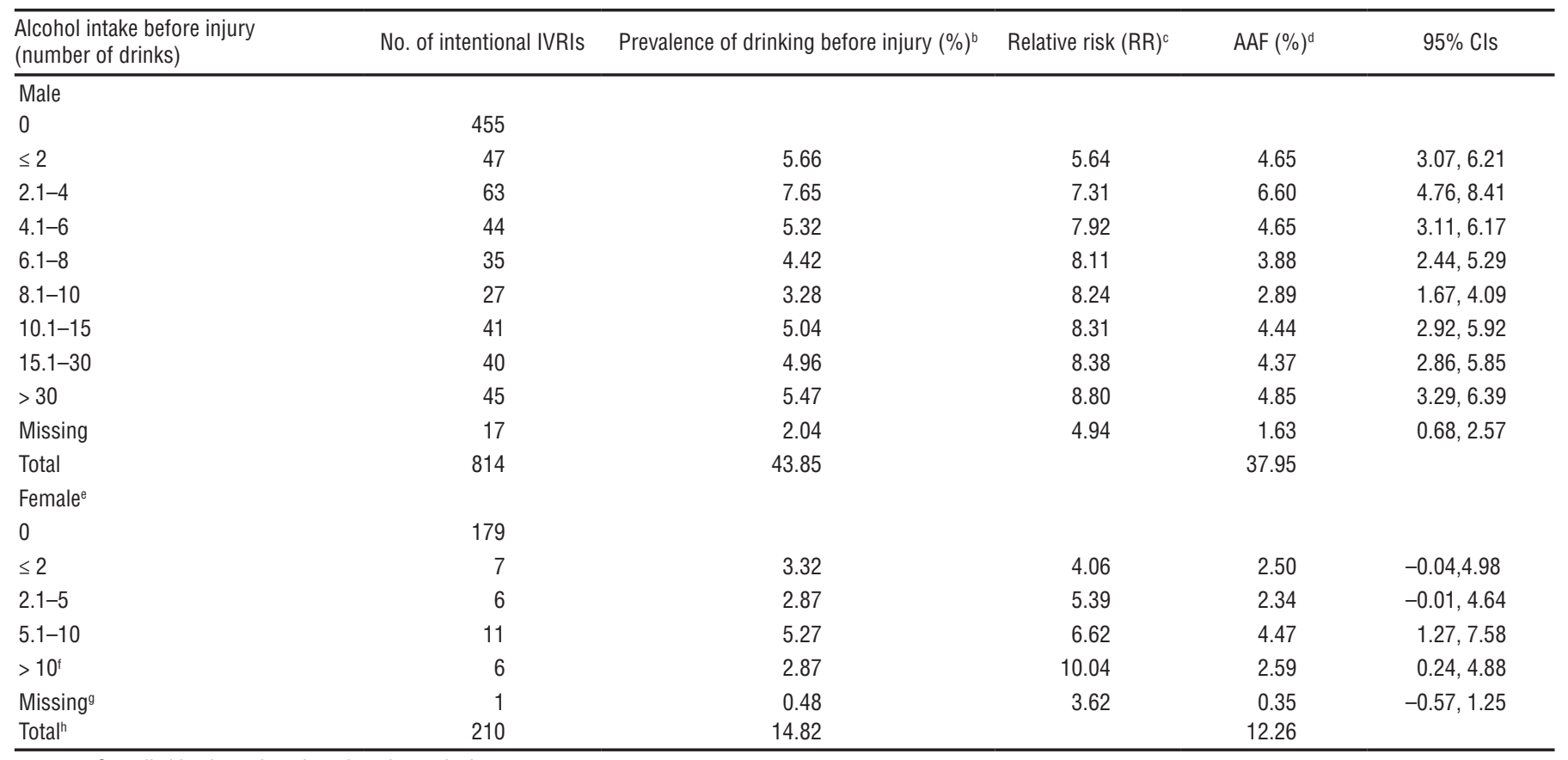

Source: Compiled by the authors based on the study data.

a Argentina, Brazil, Costa Rica, Dominican Republic, Guatemala, Guyana, Mexico, Nicaragua, Panama, Trinidad and Tobago.

${ }^{b}$ Prevalence rates are not an exact match to sample numbers because the Argentina data were weighted to adjust for uneven sampling.

' Fractional polynomial estimates based on the mean volume of each volume category (e.g., 1.35 drinks, for the $\leq 2$ drinks volume category).

${ }^{d}$ Specific-volume AAF (SVAAF): $P_{i}^{*}\left(1-1 / R R_{i}\right)$, in which $P_{i}$ is the prevalence of drinking at a given volume level among total injured patients (cases) and RR the relative risk of injury for a given volume level compared to no drinking.

${ }^{e}$ Given the small size of the female sample, some alcohol volume categories had to be collapsed.

${ }^{\dagger}$ The RR estimate for volume $>10$ drinks became very unstable for females, so the RR for that group was estimated based on a volume $=10$ drinks.

${ }^{9}$ Those who reported drinking before injury but didn't report specific volume of consumption. As a conservative estimate, the RR for 1 drink is used for this missing group.

${ }^{\mathrm{h}}$ The total includes the sum of the prevalence and SVAAF across dose levels among all patients for which drinking data were available.

attributes) that may put them at higher risk of intentional IVRI (31), the data from this study do not support that contention.

Regional variations in overall volume and patterns of consumption considered harmful to one's health have been observed (2), and other ED studies have found that drinking patterns predict alcohol-related injury $(17,18)$, with DDPs predicting AAF estimates across all injury causes (9). While harmful drinking patterns are prevalent in the Americas, where adult per capita consumption is $24 \%$ higher than the global average (2), findings from this report suggest that the AAF for intentional IVRIs in the LAC region, although high, may not be higher than that found in other countries or regions.

Differences in intentional IVRIs associated with drinking across countries and cultures may also be related to factors other than country-level DDPs, however, and the meaning of "drinking" has been found to vary across cultures, which may have an important effect on research results (32). For example, differences between societies related to both the physical context of drinking (avoidance of risky environments while drinking, etc.) and the social context of drinking (how one handles oneself while drinking or with "drunken comportment," etc.) (33), and whether or not alcohol is used as an excuse for behavior that, without it, would be socially unacceptable (e.g., disinhibition) (34), may play an important part in intentional IVRI. Although a formal rank-ordering analysis of the data shown in Table 1 was not carried out, visual examination suggests that a larger proportion of the intentional IVRIs were alcohol-related in countries with a lower prevalence of intentional IVRIs. This appears to provide support for the contention that alcohol may be used as an excuse for engaging in violent events in some societies, while in other societies in which intentional interpersonal violence-related incidents are more prevalent, alcohol may play a less prominent role. This suggests possible lines for future research on the association between alcohol and intentional IVRI, including examining the potential moderating effects of situational factors like inhibitory cues and triggering events (35), and dispositional factors like risk taking/impulsivity and sensation seeking (36).

Alcohol control policies may be another important factor affecting the study findings. Prior analysis found that alcohol policy, which differs across countries, predicted alcohol-related injury when controlling for usual drinking patterns and country-level DDPs (17), with the more stringent the policy the lower the risk of alcohol-related injury. This suggests the importance of country- and regional-level implementation of alcohol control policies such as those regulating availability of alcohol, drinking and driving, advertising, and server training 
TABLE 4. Estimated relative risk (RR) and alcohol-attributable fraction (AAF) of intentional interpersonal violence-related injuries (IVRIs) ( $n=1024)$, with $95 \%$ confidence intervals (Cls), by levels of volume consumed pre-injury, age $<30$ years $(n=586)$ and age $\geq 30$ years $(n=428)$, Latin America and the Caribbean, ${ }^{\text {a } 2001-2015}$

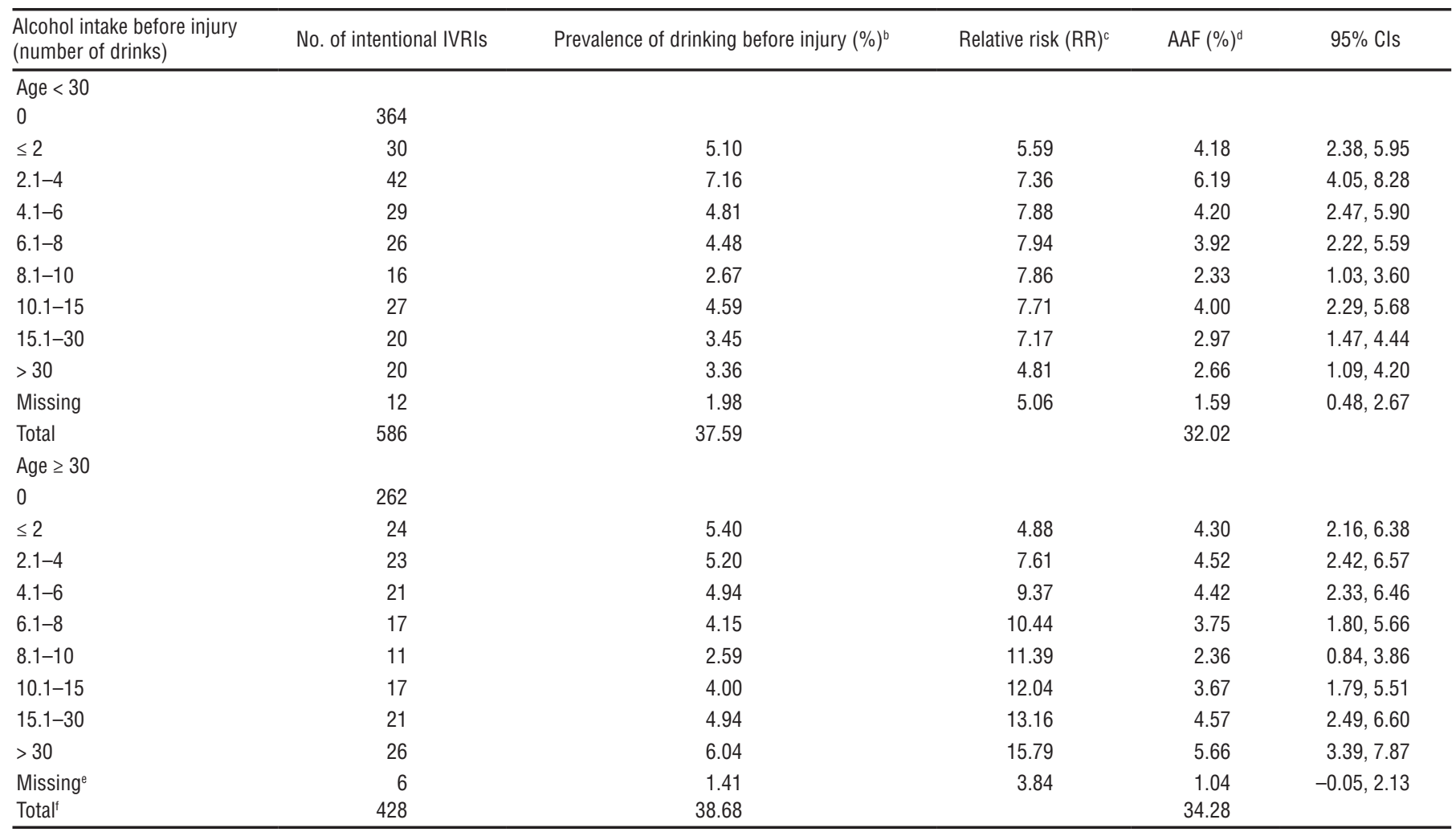

Source: Compiled by the authors based on the study data.

${ }^{a}$ Argentina, Brazil, Costa Rica, Dominican Republic, Guatemala, Guyana, Mexico, Nicaragua, Panama, Trinidad and Tobago.

${ }^{b}$ Prevalence rates are not an exact match to sample numbers because the Argentina data were weighted to adjust for uneven sampling.

${ }^{c}$ Fractional polynomial estimates based on the mean volume of each volume category (e.g., 1.35 drinks, for the $\leq 2$ drinks volume category).

${ }^{d}$ Specific-volume AAF (SVAAF): $P_{i}^{*}\left(1-1 / R R_{i}\right)$, in which $P_{i}$ is the prevalence of drinking at a given volume level among total injured patients (cases) and RR the relative risk of injury for a given volume level compared to no drinking.

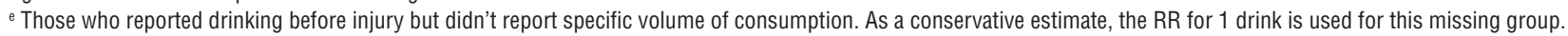

${ }^{\dagger}$ The total includes the sum of the prevalence and SVAAF across dose levels among all patients for which drinking data were available.

in preventing intentional IVRIs as well as other alcohol-related harm.

To the best of the authors' knowledge this is the first study to document the dose-response AAF for injuries related to intentional interpersonal violence, by gender and age group, in a large number of countries from the LAC region, where intentional interpersonal violence due to alcohol is thought to be high (37). A dose-response relationship was observed, with alcohol attributable for the injury in one-third of the patient samples, and the AAF was considerably smaller for females who, although at greater risk of injury than males at higher levels of consumption, drink at lower levels. No difference in the AAF was found by age, although people under age 30 were more likely to be heavier drinkers and report more alcohol-related problems than those who more than 30 years old (29). Alcohol appeared to be more likely to be involved in intentional IVRI in countries with a lower level of interpersonal aggression.

\section{Strengths and limitations}

Case-crossover analysis was used to estimate the dose-response relationship between intentional IVRI risk and alcohol, and the AAF at each volume level, a method that takes into account individual-level, "stable" characteristics such as demographic attributes, risk-taking disposition, and drinking patterns. Some caveats apply to this analytic method, however. For example, patient recall was found to deteriorate the longer the recall period in some studies (38) but not in others (39). The context in which drinking occurs prior to injury is also important to consider, as context may be associated with both the likelihood of drinking and the risk of injury from a specific cause (e.g., being in a bar or other drinking venue prior to a intentional IVRI, versus home alone, the previous week, could result in an overestimation of risk of intentional IVRI from drinking).

Also, while probability samples of patients were selected in each ED, a method designed to generate samples representative of the injured patient population in the respective ED, in more than half of the countries included in the study, only one ED was sampled, so in those countries, patient samples can not be considered representative. Even in countries where more than one ED was included, patient samples were not necessarily representative beyond the ED where the data were collected, an important consideration in interpreting the AAFs found in the study. In addition, EDs where data were collected were primarily located in large metropolitan areas, so relationships 
found here between alcohol consumption and intentional IVRI may not apply to the more rural areas of the country, where demographic profiles may be different.

In addition, while most of the data were collected over a period spanning five years, at three of the country sites, the data were collected in the more distant past. Therefore, although the data were cross-sectional at each site, the study findings for those three countries may be more reflective of past, versus current, associations. Also, general population studies have found that those reporting being treated in the ED for an injury tend to be heavier drinkers than those reporting obtaining treatment from other sources or not obtaining any treatment for their injury, and the former group of individuals has been found to have larger RRs and AAFs for injury (40).

Another potential limitation is that the RR and AAF for intentional IVRI may have been underestimated, as the calculations were based solely on the selfreported alcohol consumption of the patient before the injury (i.e., they did not include the potential contribution of others' drinking prior to the event, which has been found to be substantial). In prior analyses of intentional IVRI across 14 countries, a $62 \%$ increase was found in the AAF when perpetrators of the event who had been drinking and whose drinking was causally associated with the event, according to the patients, were included in the analysis, along with the patients who believed the event would not have occurred if they, themselves, had not been drinking (41). Thus, only part of the alcohol-attributable intentional interpersonal violence problem is being analyzed here-that resulting in an injury that requires ED treatment, for either the victim or the offender-leaving out alcohol-attributable intentional interpersonal was presented at the $12^{\text {th }}$ World
Conference on Injury Prevention and Safety Promotion in Tampere, Finland, October 18-21, 2016, is based, in part, on data collected by collaborators of 1) the Emergency Room Collaborative Alcohol Analysis Project (ERCAAP), including C.J. Cherpitel (principal investigator, United States) and J. Bejarano (Costa Rica); 2) the WHO Collaborative Study on Alcohol and Injuries (implemented by the WHO Collaborative Study Group on Alcohol and Injuries under the direction of V. Poznyak and M. Peden (WHO)), including G. Borges (Mexico), M. Cremonte (Argentina), and N. Figlie and R. Larajeira (Brazil) (complete list of project contributors available at http://www.who. int/substance_abuse/publications/alcohol_injuries_final_report.pdf); and 3) the Pan American Health Organization Collaborative Study on Alcohol and Injuries, directed by M. Monteiro (PAHO) and implemented by C.J. Cherpitel and G. Borges (Mexico), V. Aparicio and A. de Bradshaw (Panama), V. Lopez (Guatemala), M. Paltoo (Guyana), E. Perez (Dominican Republic), S. Reid (Trinidad and Tobago), and D. Weil (Nicaragua).

Funding. Supported by a grant from the U.S. National Institute on Alcohol Abuse and Alcoholism (NIAAA) (RO1 5 AA013750).

\section{Conflicts of interest. None.}

Disclaimer. Authors hold sole responsibility for the views expressed in the manuscript, which may not necessarily reflect the opinion or policy of the RPSP / PAJPH, the Pan American Health Organization (PAHO), the World Health Organization, or the other investigators participating in the ERCAAP, WHO, or PAHO collaborative studies on alcohol and injuries described above.

\section{REFERENCES}

1. Institute for Health Metrics and Evaluation. Global Burden of Diseases, Injuries, and Risk Factors Study 2010 (GBD 2010). Seattle: University of Washington; 2013.

2. Shield KD, Monteiro M, Roerecke $M$, Smith B, Rehm J. Alcohol consumption and burden of disease in the Americas in 2012: implications for alcohol policy. Rev Panam Salud Publica. 2015;38(6):442-9. Available from: http:/ / www.scielosp.org/scielo.php? script=sci_arttext\&pid=S1020-4989201 $5001100002 \& \operatorname{lng}=\mathrm{en} \& n \mathrm{~nm}=\mathrm{iso} \& \operatorname{tn} \mathrm{l}=\mathrm{en}$
3. Corrao G, Bagnardi V, Zambon A, Arico S. Exploring the dose-response relationship between alcohol consumption and the risk of several alcohol-related conditions: a meta-analysis. Addiction. 1999; 94(10):1551-73. doi: 10.1046/j.1360-0443. 1999.9410155111.x.

4. Rehm J, Baliunas D, Borges GLG, Graham K, Irving $\mathrm{H}$, Kehoe $\mathrm{T}$, et al. The relation between different dimensions of alcohol consumption and burden of disease: an overview. Addiction. 2010;105(5):817-43. doi: 10.1111/j.1360-0443.2010.02899.x.
5. Smith GS, Branas CC, Miller TR. Fatal nontraffic injuries involving alcohol: a metaanalysis. Ann Emerg Med. 1999; 33(6):659-68. doi:10.1016/j.cpr.2008.05.001.

6. Foran HM, O'Leary KD. Alcohol and intimate partner violence: a meta-analytic review. Clin Psychol Rev. 2008;28(7):1222-34

7. Cherpitel CJ. Alcohol and violence-related injuries in the emergency room. In: Galanter M, Begleiter H, Deitrich R, Fuller R, Gallant D, Goodwin D, et al., editors. Recent developments in alcoholism. Volume 13: alcohol and violence-epidemiology, neurobiology, 
psychology, family issues. New York: Plenum Press; 1997. Pp. 105-18.

8. Cherpitel CJ. Alcohol and injuries: a review of international emergency room studies since 1995. Drug Alcohol Rev. 2007;26(2):201-14. doi: 10.1080/09595230 601146686

9. Cherpitel CJ, Ye Y, Bond J. Attributable risk of injury associated with alcohol use: cross-national data from the Emergency Room Collaborative Alcohol Analysis Project. Am J Public Health. 2005;95(2):26672. doi: 10.2105/AJPH.2003.031179.

10. Vinson DC, Borges G, Cherpitel CJ. The risk of intentional injury with acute and chronic alcohol exposures: a case-control and case-crossover study. J Stud Alcohol. 2003;64(3):350-7. doi: 10.15288/jsa.2003. 64.350 .

11. Borges G, Cherpitel CJ, Mondragón L, Poznyak V, Peden M, Gutiérrez I. Episodic alcohol use and risk of nonfatal injury. Am J Epidemiol. 2004;159(6):565-71.

12. Borges G, Cherpitel CJ, Orozco R, Bond J, Ye Y, Macdonald S, et al. Multicentre study of acute alcohol use and non-fatal injuries: data from the WHO collaborative study on alcohol and injuries. Bull World Health Organ. 2006;84(6):453-60. doi: 10.1590/ S0042-96862006000600014.

13. Cherpitel CJ, Ye Y, Bond J, Borges G, Monteiro M. Relative risk of injury from acute alcohol consumption: modeling the dose-response relationship in emergency department data from 18 countries. Addiction. 2015;110(2):279-88. doi: 10.1111/ add. 12755 .

14. Taylor B, Irving HM, Kanteres F, Room R, Borges G, Cherpitel CJ, et al. The more you drink, the harder you fall: a systematic review and meta-analysis of how acute alcohol consumption and injury or collision risk increase together. Drug Alcohol Depend. 2010;110(1-2):108-16. doi: 10.1016/j.drugalcdep.2010.02.011.

15. Kuendig H, Hasselberg M, Laflamme L, Daeppen JB, Gmel G. Acute alcohol consumption and injury: risk associations and attributable fractions for different injury mechanisms. J Stud Alcohol Drugs. 2008;69(2):218-26. doi: 10.15288/ jsad.2008.69.218.

16. Cherpitel CJ, Ye Y, Bond J, Borges G, Monteiro M, Chou P, et al. Alcohol attributable fraction for injury morbidity from the dose-response relationship of acute alcohol consumption: emergency department data from 18 countries. Addiction. 2015;110(11):1724-32. doi: 10.1111/add. 13031.

17. Cherpitel CJ, Ye Y, Bond J, Borges G, Chou $P$, Nilsen P, et al. Multi-level analysis of alcohol-related injury and drinking pattern: emergency department data from 19 countries. Addiction. 2012;107(7):1263-72. doi: 10.1111/j.1360-0443.2012.03793.x.

18. Cherpitel CJ, Borges G, Giesbrecht N, Monteiro M, Stockwell $\mathrm{T}$, editors. Prevention of alcohol-related injuries in the Americas: from evidence to policy action. Washington: Pan American Health Organization; 2013. Available from: http:/ / apps.who.int/iris/bitstream / 10665/173355/1/Prevention\%20of\%20alcohol-related\%202013.pdf
19. Rehm J, Monteiro M, Room R, Gmel G, Jernigan D, Frick U, et al. Steps towards constructing a global comparative risk analysis for alcohol consumption: determining indicators and empirical weights for patterns of drinking, deciding about theoretical minimum, and dealing with different consequences. Eur Addict Res. 2001;7(3):138-47. doi: 10.1159/000050731.

20. World Health Organization. Global status report on alcohol and health 2014. Geneva: WHO; 2014. Available from: http://www. who.int/substance_abuse/publications / global_alcohol_report/en/ Accessed on 31 May 2016.

21. Lim SS, Vos T, Flaxman AD, Danaei G, Shibuya K, Adair-Rohani H, et al. A comparative risk assessment of burden of disease and injury attributable to 67 risk factor and risk factor clusters in 21 regions, 1990-2010: a systematic analysis for the Global Burden of Disease Study 2010. Lancet. 2012;380(9859):2224-60. doi: 10.1016/S0140-6736(12)61766-8.

22. da Silva RL, Diehl A, Cherpitel CJ, Figlie NB. Violence and non-violence-related injuries and alcohol in women from developed and developing countries: a multi-site emergency room study. Addict Behav. 2015;41:252-5. doi: 10.1016/j. addbeh.2014.10.014.

23. Babor T, Caetano R, Casswell S, Edwards G, Giesbrecht N, Graham K, et al. Alcohol: no ordinary commodity: research and public policy. New York: Oxford University Press; 2003.

24. Cherpitel CJS. A study of alcohol use and injuries among emergency room patients. In: Giesbrecht N, Gonzales R, Grant M, Österberg E, Room R, Rootman I, et al., editors. Drinking and casualties: accidents, poisonings and violence in an international perspective. New York: Tavistock/ Routledge; 1989. Pp. 288-99.

25. Maclure M. The case-crossover design: a method for studying transient effects on the risk of acute events. Am J Epidemiol. 1991;133(2):144-53.

26. Royston P, Altman DG. Regression using fractional polynomials of continuous covariates: parsimonious parametric modeling. Appl Stat. 1994;43(3):429-67.

27. StataCorp. Stata Statistical Software: release 13. College Station, TX: StataCorp LP; 2013.

28. Steenland K, Armstrong B. An overview of methods for calculating the burden of disease due to specific risk factors. Epidemiology. 2006;17(5):512-9. doi: $10.2307 / 2986270$.

29. Substance Abuse and Mental Health Services Administration. National survey on drug use and health: comparison of 2002-2003 and 2013-2014 population percentages (50 states and the District of Columbia). Rockville, MD: SAMHSA; 2015. Available from: http://www. samhsa.gov/data/sites/default/files / NSDUHsaeLongTermCHG2014/NSDUH saeLongTermCHG2014.pdf Accessed on 23 March 2016.

30. Wells S, Thompson JM, Cherpitel C, Macdonald S, Marais S, Borges G. Gender differences in the relationship between alcohol and violent injury: an analysis of cross-national emergency department data. J Stud Alcohol Drugs. 2007;68(6): 824-33.

31. Watt K, Purdie DM, Roche AM, McClure RJ. Risk of injury from acute alcohol consumption and the influence of confounders. Addiction. 2004;99(10):1262-73. doi: $10.1111 / j .1360-0443.2004 .00823 . x$.

32. Room R. Intoxication and bad behaviour: understanding cultural differences in the link. Soc Sci Med. 2001;53(2):189-98. doi: 10.1016/S0277-9536(00)00330-0.

33. MacAndrew C, Edgerton RB. Drunken comportment: a social explanation. Chicago: Aldine; 1969.

34. Room R, Collins G, editors. Alcohol and disinhibition: nature and meaning of the link. Proceedings of a conference (Berkeley/Oakland, California, February 11-13, 1981). Rockville, MD: U.S. Department of Health and Human Services; 1983. Available from: http:// files.eric.ed.gov/fulltext/ED247515.pdf

35. Ito TA, Miller N, Pollock VE. Alcohol and aggression: a meta-analysis on the moderating effects of inhibitory cues, triggering events, and self-focused attention. Psychol Bull. 1996;120(1):60-82. doi: 10.1037/ 0033-2909.120.1.60.

36. Cherpitel CJ. Alcohol, injury, and risk-taking behavior: data from a national sample. Alcohol Clin Exp Res. 1993;17(4):762-6. doi: 10.1111/j.1530-0277.1993.tb00837.x.

37. Graham K, Bernards S, Munné $M$, Wilsnack S, editors. Unhappy hours: alcohol and partner aggression in the Americas. Washington: Pan American Health Organization; 2009. Available from: http://apps.who.int/bookorders/ anglais $/$ detart 1 .jsp? codlan $=1 \& \operatorname{cod} c o l=$ $61 \& \operatorname{cod} c \mathrm{ch}=631$

38. Gmel G, Daeppen JB. Recall bias for sevenday recall measurement of alcohol consumption among emergency department patients: implications for case-crossover designs. J Stud Alcohol Drugs. 2007; 68(2):303-10. doi: 10.15288/jsad.2007.68. 303.

39. Ye Y, Bond J, Cherpitel CJ, Borges G, Monteiro M, Vallance K. Evaluating recall bias in a case-crossover design estimating risk of injury related to alcohol: data from six countries. Drug Alcohol Rev. 2013;32(5):512-8. doi: 10.1111/dar.12042.

40. Cherpitel CJ, Ye Y. Alcohol-attributable fraction for injury in the U.S. general population: data from the 2005 National Alcohol Survey. J Stud Alcohol Drugs. 2008;69(4):535-8. doi: 10.15288/jsad.2008. 69.535.

41. Cherpitel CJ, Ye Y, Bond J, Room R, Borges G. Attribution of alcohol to violence-related injury: self and others' drinking in the event. J Stud Alcohol Drugs. 2012;73(2):227-84. Available from: https: / www.ncbi.nlm.nih.gov/pmc/articles/PMC3281985/

Manuscript submitted 12 January 2017. Revised version accepted for publication on 30 May 2017. 
RESUMEN Objetivo. Determinar el riesgo relativo (RR) de la carga social de los traumatismos relacionados con actos de violencia interpersonal intencional atribuibles al alcohol (fracción atribuible al alcohol o AAF) y la relación dosis-efecto en América Latina y el

\section{Riesgo de traumatismos relacionados con la violencia producto del consumo de alcohol y su carga social en América Latina y el Caribe}

Palabras clave
Caribe, donde se cree que tanto el RR como la AAF por traumatismos relacionados con la violencia son particularmente altos.

Métodos. Se estudió una muestra probabilística de 1024 pacientes que ingresaron al servicio de urgencias de 10 países de América Latina y el Caribe y que declararon un traumatismo relacionado con un acto de violencia interpersonal (IVRI) intencional, usando para ello un análisis polinomial fraccionario con cruce de casos del número de bebidas consumidas antes del incidente.

Resultados. Se observó una relación dosis-efecto con un aumento de seis veces el riesgo $(R R=5,6)$ con hasta dos bebidas antes del traumatismo. El riesgo fue mayor para: 1) las mujeres respecto de los hombres con más de 10 bebidas y 2) los hombres y mujeres mayores de 30 años de edad frente a los menores de 30 años en todos los niveles de volumen. En términos generales, 32,7\% de los 1024 IVRI intencionales fueron atribuibles al alcohol. La AAF fue tres veces mayor para los hombres (38\%) que para las mujeres $(12,3 \%)$.

Conclusiones. Se observó una relación dosis-efecto entre el volumen de alcohol consumido antes del incidente y el riesgo de IVRI intencional. El riesgo no fue uniforme entre los dos sexos ni en todas las edades. Las mujeres tuvieron un riesgo mayor de traumatismo en comparación con los hombres a volúmenes mayores de consumo, pero tuvieron una AAF más baja debido a una prevalencia más baja del consumo de alcohol en mayores cantidades.

Violencia; heridas y lesiones; riesgo; consumo de bebidas alcohólicas; América Latina; Región del Caribe.
RESUMO

\section{Risco de lesões resultantes da violência associada ao uso de álcool e o ônus à sociedade na América Latina e no Caribe}

Palavras-chave
Objetivo. Determinar o risco relativo (RR) e o ônus à sociedade de lesões intencionais resultantes da violência interpessoal atribuível ao uso de álcool (fração de risco atribuível ao consumo de álcool, FAA) e a relação de dose-resposta na América Latina e no Caribe (ALC). Acredita-se que o RR e a FAA de lesões resultantes da violência sejam particularmente altos na região.

Métodos. Foi estudada uma amostra probabilística englobando 1.024 pacientes atendidos no setor de emergência de 10 países da ALC por lesão intencional resultante de violência interpessoal (LIVI). Foi realizado um estudo de caso-cruzado com análise polinomial fracionada do número de doses de bebida alcoólica consumidas antes do evento.

Resultados. Verificou-se uma relação de dose-resposta com aumento do risco de seis vezes $(R R=5,6)$ associado a duas doses ou menos de bebida alcoólica consumidas antes da ocorrência das lesões. O risco foi maior: 1) no sexo feminino em comparação ao masculino com o consumo acima de 10 doses de bebida alcoólica e 2) em indivíduos do sexo masculino e feminino com acima de 30 anos em comparação aos indivíduos com idade abaixo de 30 anos em todos os níveis de consumo. De modo geral, 32,7\% das 1.024 LIVI foram atribuíveis ao consumo de álcool. A FAA foi três vezes maior no sexo masculino (38\%) que no feminino (12,3\%).

Conclusões. Observou-se uma relação de dose-resposta entre o nível de consumo de álcool antes do evento e o risco de LIVI. O risco variou por sexo ou idade. Em comparação aos homens, as mulheres apresentaram maior risco de lesão nos níveis mais elevados de consumo de álcool, porém com FAA menor devido à baixa prevalência do consumo de álcool nestes níveis.

Violência; ferimentos e lesões; risco; consumo de bebidas alcoólicas; América Latina; Região do Caribe. 